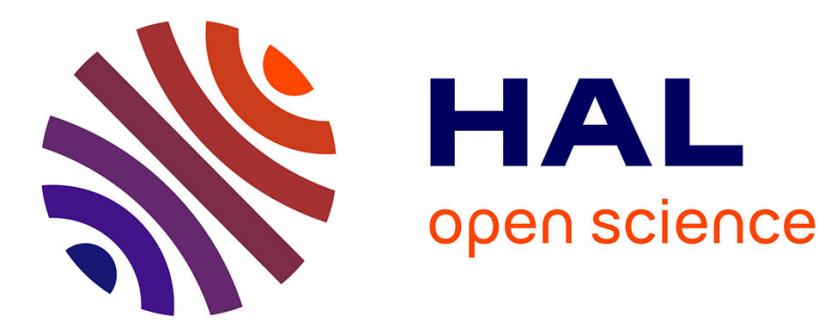

\title{
Effect of low loading of yttrium on Ni-based layered double hydroxides in $\mathrm{CO} 2$ reforming of $\mathrm{CH} 4$
}

Katarzyna Świrk, Monika Motak, Teresa Grzybek, Magnus Rønning, Patrick da Costa

\section{- To cite this version:}

Katarzyna Świrk, Monika Motak, Teresa Grzybek, Magnus Rønning, Patrick da Costa. Effect of low loading of yttrium on Ni-based layered double hydroxides in $\mathrm{CO} 2$ reforming of $\mathrm{CH} 4$. Reaction kinetics, mechanisms and catalysis, In press, 10.1007/s11144-018-1515-9 . hal-02057554

\section{HAL Id: hal-02057554 https://hal.sorbonne-universite.fr/hal-02057554}

Submitted on 5 Mar 2019

HAL is a multi-disciplinary open access archive for the deposit and dissemination of scientific research documents, whether they are published or not. The documents may come from teaching and research institutions in France or abroad, or from public or private research centers.
L'archive ouverte pluridisciplinaire $\mathbf{H A L}$, est destinée au dépôt et à la diffusion de documents scientifiques de niveau recherche, publiés ou non, émanant des établissements d'enseignement et de recherche français ou étrangers, des laboratoires publics ou privés. 


\title{
Effect of low loading of yttrium on Ni-based layered double
}

\section{hydroxides in $\mathrm{CO}_{2}$ reforming of $\mathrm{CH}_{4}$}

\section{Katarzyna Świrk ${ }^{1,2, *}$,Monika Motak², Teresa Grzybek², Magnus Rønning³, Patrick Da Costa $^{1}$}

${ }^{1}$ Sorbonne Université, CNRS, Institut Jean le Rond d'Alembert, F-78210 Saint-Cyr l'École, France

${ }^{2}$ AGH University of Science and Technology, Department of Fuel Technology, 30-059 Cracow, Poland

${ }^{3}$ Norwegian University of Science and Technology, Department of Chemical Engineering, N7491 Trondheim, Norway

\begin{abstract}
$\mathrm{Ni} / \mathrm{Al} / \mathrm{Mg}$ layered double hydroxides (LDHs) modified with low loading of yttrium (0.2 and $0.4 \mathrm{wt} \%$ ) were used in dry reforming of methane at $700{ }^{\circ} \mathrm{C}$. Physicochemical characterization, such as: X-ray fluorescence, $\mathrm{N}_{2}$ sorption, $\mathrm{X}$-ray diffraction, temperature programmed reduction in $\mathrm{H}_{2}$, temperature programmed desorption of $\mathrm{CO}_{2}, \mathrm{H}_{2}$ chemisorption, thermogravimetry analysis coupled by mass spectrometry and Raman spectroscopy, showed that the introduction of low loadings of yttrium lead to a smaller $\mathrm{Ni}^{\mathrm{o}}$ crystallite size, a decrease in reducibility of the nickel, and a decreased number of basic sites in the modified Ni/LDHs catalysts. The doping with $0.4 \mathrm{wt} \%$ of $\mathrm{Y}$ improves catalytic activity resulting in higher $\mathrm{CH}_{4}$ and $\mathrm{CO}_{2}$ conversions at $700{ }^{\circ} \mathrm{C}$, i.e. ca. $84 \%$ and ca. $87 \%$, respectively with no clear deactivation observed after $5 \mathrm{~h}$ run. The increase in $\mathrm{CO}_{2}$ conversion and a decrease of $\mathrm{H}_{2} / \mathrm{CO}$ ratio indicates that side reactions occurs during DRM.
\end{abstract}

Keywords: dry reforming of methane, nickel, yttrium, layered double hydroxides

*Corresponding author: Katarzyna Świrk (swirk@agh.edu.pl , katarzyna.swirk@,sorbonne$\underline{\text { univeriste.fr) }}$ 


\section{Introduction}

With a view to enhancing chemical $\mathrm{CO}_{2}$ utilization technologies, dry methane reforming (DRM) is a one of the prospective processes, which allows to convert carbon dioxide and methane into valuable products, i.e. synthesis gas (equation 1). The process is complex and consists of several steps, in which the most important are the reactions mentioned below [1,2]:

$$
\begin{array}{ll}
\mathrm{CH}_{4}+\mathrm{CO}_{2}=2 \mathrm{CO}+2 \mathrm{H}_{2}, & \Delta \mathrm{H}^{\theta}=247 \mathrm{~kJ} / \mathrm{mol} \\
\mathrm{CO}_{2}+\mathrm{H}_{2}=\mathrm{H}_{2} \mathrm{O}+\mathrm{CO}, & \Delta \mathrm{H}^{\theta}=41 \mathrm{~kJ} / \mathrm{mol} \\
2 \mathrm{CO}=\mathrm{C}_{(\mathrm{s})}+\mathrm{CO}_{2}, & \Delta \mathrm{H}^{\theta}=-172 \mathrm{~kJ} / \mathrm{mol} \\
\mathrm{CH}_{4}=\mathrm{C}_{(\mathrm{s})}+2 \mathrm{H}_{2}, & \Delta \mathrm{H}^{\theta}=75 \mathrm{~kJ} / \mathrm{mol}
\end{array}
$$

The industrialization of DRM is, however, limited by a high reaction temperature (at least $642{ }^{\circ} \mathrm{C}$ ), which increases the economic costs of process, and by undesirable coke formation (equations 3 and 4) which causes the catalyst deactivation [3]. Supported noble metal catalysts ( $\mathrm{Rh}, \mathrm{Ru}, \mathrm{Ir}, \mathrm{Pt}$ and $\mathrm{Pd}$ ) show efficient catalytic performance and low sensitivity to carbon deposits, but their high price and low availability prevent their industrial application in contrast to Ni-based catalysts. The latter represent a promising alternative [4-7]. However, the main drawback of their application is fast deactivation caused by coke formation, sintering of active phase and metal oxidation $[2,8,9]$. The deactivation may be limited due to possible improvement of the physical properties, e.g. Ni particle size lower than $10 \mathrm{~nm}$ and high dispersion of the metal species $[10,11]$. Thus, finding a highly active, selective and stable catalyst remains a serious problem for industrialization of DRM and the preparation of a novel catalyst is still a challenge $[12,13]$. The choice of proper support may contribute to an improvement.

Synthetic layered double hydroxides (LDHs), show good properties as precursors due to their double layered and homogenous structure with appropriate basic properties and the presence of $\mathrm{Mg}^{2+}$ and $\mathrm{Al}^{3+}$ introduced by co-precipitation method. These cations may by 
partially substituted by ions of promoter, in order to improve properties of the material [1417].

A large number of studies have shown that Ni-based catalysts can result in high activity and stability in DRM [18-27].

Yttrium has received considerable attention as a promising promoter for many chemical processes [28-33], including dry reforming of methane [34-37]. Recently, yttrium promotion $(0.2-0.6 \mathrm{wt} \%)$ was examined by us over Ni-based catalysts, which were additionally modified with $\mathrm{Zr}$ [33]. The promotion with $\mathrm{Zr}(5 \mathrm{wt} \%)$ and $\mathrm{Y}(0.4 \mathrm{wt} \%)$ resulted in an enhanced stability and activity which could be ascribed to the formation of $\mathrm{ZrO}_{2}-\mathrm{Y}_{2} \mathrm{O}_{3}$, the latter possibly leading to the reduction of bulk NiO. Bellido et al. [38] also synthesized Zr-modified Ni-containing catalysts with a varying mole fraction of Y (4 to $12 \mathrm{~mol} \%$ ). The catalyst modified with $8 \mathrm{~mol} \%$ showed the highest activity and stability in the DRM, possibly due to the increased formation of oxygen vacancies. The effect of higher Y-loadings ( 0.6 and $1.5 \mathrm{wt} \%)$ on Ni/Mg/Al layereddouble hydroxides was also studied elsewhere [3]. The modification with these quantities resulted in the increased specific surface area, smaller Ni crystallite size, enhanced dispersion of active sites, changes in the reducibility and higher distribution of weak and medium basic sites as compared to the unpromoted catalyst. The modification with higher amount of yttrium $(1.5 \mathrm{wt} \%)$ showed enhanced stability in the dry reforming of methane tests.

No study concerning the effect of low yttrium loading (lower than $0.6 \mathrm{wt} \%$ ) on Ni-LDHs has been reported before. Thus, the aim of this work was to examine the influence of the yttrium promotion ( 0.2 and $0.4 \mathrm{wt} \%)$ of Ni-based layered double-hydroxides on their structure and catalytic behavior in dry reforming of methane. 


\section{Experimental}

\subsection{Catalysts preparation}

The layered double hydroxides were synthesized by co-precipitation method. An aqueous solution of following salts was used: $\mathrm{Mg}\left(\mathrm{NO}_{3}\right) \cdot 6 \mathrm{H}_{2} \mathrm{O}$ (Sigma Aldrich, 99\% pure), $\mathrm{Ni}\left(\mathrm{NO}_{3}\right)_{2} \cdot 6 \mathrm{H}_{2} \mathrm{O}$ (Sigma Aldrich, 98.5\% pure), $\mathrm{Al}\left(\mathrm{NO}_{3}\right)_{2} \cdot 9 \mathrm{H}_{2} \mathrm{O}$ (Fluka, 98\% pure) and $\mathrm{Y}\left(\mathrm{NO}_{3}\right)_{3} \cdot 6 \mathrm{H}_{2} \mathrm{O}$ (Aldrich, $99.8 \%$ pure), together with a $2 \mathrm{M}$ solution of $\mathrm{NaOH}$ to control $\mathrm{pH}$. These two solutions have been added dropwise to sodium carbonate solution $(\mathrm{cp}=25 \%)$. The $\mathrm{pH}$ of a mixture was kept in the range of 9.8-10.2. The synthesis of the materials assumed ratio $\mathrm{M}^{2+} / \mathrm{M}^{3+}=3.0$. In individual sample the following content of yttrium was doped 0.2 and 0.4 $\mathrm{wt} \%$. After co-precipitation of the salts, the mixture was aged for $24 \mathrm{~h}$, and the slurry was then filtered and washed with distilled water. The final product was calcined in air at $550{ }^{\circ} \mathrm{C}$ for $5 \mathrm{~h}$. So prepared catalysts were labeled HTNi, HTNi-Y0.2 and HTNi-Y0.4.

\subsection{Catalysts characterization}

X-Ray Fluorescence (XRF) analysis was used to examine elemental composition in the Ni catalysts after calcination. The analysis was carried out by using a Supermini200 instrument. The samples were kept under vacuum at $36.5{ }^{\circ} \mathrm{C}$ in the presence of P-10 gas (flow 24.7 $\left.\mathrm{cm}^{3} / \mathrm{min}\right)$. The powdered materials were diluted in boric acid and pelletized under a press (10 bar). The pellets were covered with $6 \mu \mathrm{m}$ polypropylene film.

Nitrogen sorption was performed by a Micromeritics TriStar II 3020 in order to determine textural properties of the materials. The samples were degassed for $3 \mathrm{~h}$ at $110{ }^{\circ} \mathrm{C}$ before the measurement. Nitrogen sorption isotherms were measured at liquid-nitrogen temperature of $195{ }^{\circ} \mathrm{C}$. 
X-ray diffraction (XRD) patterns were obtained from PANalytical-Empyrean diffractometer, equipped with $\mathrm{CuK} \alpha(\lambda=0.15406 \mathrm{~nm})$ radiation source. The average crystallite size of Ni was determined from the Scherrer equation.

Temperature-programmed reduction $\left(\mathrm{TPR}-\mathrm{H}_{2}\right)$ measurements were carried out on a BEL Japan BELCAT-M equipped with a thermal conductivity detector (TCD). Calcined materials $(60 \mathrm{mg})$ were first degassed in helium atmosphere at $100{ }^{\circ} \mathrm{C}$ for $2 \mathrm{~h}$ and then reduced in $5 \%$ $\mathrm{H}_{2} / \mathrm{Ar}$ mixture with a heating rate of $10{ }^{\circ} \mathrm{C} / \mathrm{min}$ starting from $100{ }^{\circ} \mathrm{C}$ to $900{ }^{\circ} \mathrm{C}$. The measurements of temperature programmed desorption (TPD-CO $\mathrm{CO}_{2}$ ) were performed for the sample just after TPR- $\mathrm{H}_{2}$ test, using the same apparatus. $\mathrm{CO}_{2}$ was adsorbed at $80{ }^{\circ} \mathrm{C}$ for $1 \mathrm{~h}$ from a mixture of $10 \% \mathrm{CO}_{2} / \mathrm{He}$. Then, helium flow was applied for $15 \mathrm{~min}$ in order to desorb weakly adsorbed $\mathrm{CO}_{2}$. Finally, the materials were heated from $80{ }^{\circ} \mathrm{C}$ to $800{ }^{\circ} \mathrm{C}$ in helium in order to determine weak, medium and strong basic sites based on temperature of desorption. TPD profiles were deconvoluted into three Gaussian peaks.

Hydrogen chemisorption was used to determine nickel dispersion (Micromeritics, ASAP 2020S). $200 \mathrm{mg}$ of calcined materials were loaded in tubular quartz reactor. Prior the experiments, evacuation at $40^{\circ} \mathrm{C}$ for $1 \mathrm{~h}$ and reduction in pure $\mathrm{H}_{2}$ at $900{ }^{\circ} \mathrm{C}$ for $1 \mathrm{~h}$ was applied. After the reduction, the sample was evacuated in helium for $30 \mathrm{~min}$ at $900{ }^{\circ} \mathrm{C}$ and subsequently for $1 \mathrm{~h}$ at $40{ }^{\circ} \mathrm{C}$. After the leak test pass, the sample was continuously evacuated for $30 \mathrm{~min}$ at $40{ }^{\circ} \mathrm{C}$, at this temperature, an adsorption isotherm was recorded and the metal dispersion was determined based on the quantity of hydrogen uptake. Also, Ni crystallite size was calculated, assuming spherical metal crystallites of uniform diameter $d$ [39]:

$$
d=\frac{97.1}{96 D} \quad[\mathrm{~nm}]
$$

In which 97.1 represents a constant for nickel and $\% D$ the percentage dispersion obtained from $\mathrm{H}_{2}$ chemisorption. 
Thermogravimetric analyzes were carried out by a TGA-MS (TGA: Netzsch STA 449C Jupiter, MS: Netzsch Aërlos QMS 403C) in order to evaluate the coke formation on spent catalysts. An air flow of $100 \mathrm{~cm}^{3} / \mathrm{min}$ and protective gas flow of $20 \mathrm{~cm}^{3} /$ min were applied. 10 mg of a spent sample was heated starting from ambient temperature to $900{ }^{\circ} \mathrm{C}$ with a ramp rate of $10^{\circ} \mathrm{C} / \mathrm{min}$. The amount of coke deposition was estimated by the mass loss in TGA analysis, confirming by $\mathrm{CO}_{2}$ production derived from MS results.

Raman was employed to characterize carbon deposits formed on the spent catalysts by using a Horiba Jobin Yvon LabRam HR800 instrument. The spectra were recorded with a laser excitation wavelength of $633 \mathrm{~nm}$ at an accumulation of 3 and an acquisition time of $20 \mathrm{~s}$. A diffraction grating of $1800 \mathrm{gr} / \mathrm{mm}$ and a 50x objective were applied.

\subsection{Catalytic tests}

The catalytic DRM tests were conducted under atmospheric pressure, in a fixed-bed U type reactor $(8 \mathrm{~mm}$ inner diameter). The catalytic bed temperature was monitored by a K-type thermocouple placed in a quartz shield. Calcined catalysts were introduced into the reactor and reduced in situ earlier to the reaction in flowing a mixture of $5 \% \mathrm{H}_{2} / \mathrm{Ar}$ (flow $50 \mathrm{~cm}^{3} / \mathrm{min}$ ) at $900{ }^{\circ} \mathrm{C}$ for $1 \mathrm{~h}$ to activate the catalyst in-situ. Then two types of tests were carried out.

A first series of the experiments were performed in the temperature range of $850-600{ }^{\circ} \mathrm{C}$ with a temperature step every $50{ }^{\circ} \mathrm{C}$, and cooling time of 15 min between the steps. The duration of the test at each temperature was 30 minutes corresponding to steady-state measurements.

A second series of experiments were carried out in isothermal conditions at $700{ }^{\circ} \mathrm{C}$ for 5 hours in order to evaluate the catalysts initial stability.

For both experiments, the gas composition was equal to $\mathrm{CH}_{4} / \mathrm{CO}_{2} / \mathrm{Ar}=1 / 1 / 8$. The total flow was $100 \mathrm{~cm}^{3} / \mathrm{min}$ which corresponds to a gas hourly space velocity (GHSV) of $20,000 \mathrm{~h}^{-1}$. The outlet gases were analyzed by gas chromatograph (490 Varian Micro-GC). In order to acquire 
$\mathrm{CH}_{4}, \mathrm{CO}_{2}$, conversions as well as the $\mathrm{H}_{2} / \mathrm{CO}$ ratios the following equations (6), (7), (8) were employed:

$$
\begin{array}{ll}
X_{\mathrm{CH}_{4}}=\left[\frac{{ }_{\mathrm{CH}_{4}^{\text {in }}}-n_{\mathrm{CH}_{4}^{\text {out }}}}{n_{\mathrm{CH}_{4}^{\text {in }}}}\right] \cdot 100 & {[\%]} \\
X_{\mathrm{CO}_{2}}=\left[\frac{{ }_{\mathrm{CO}_{3}^{\text {in }}}-n_{\mathrm{CO}_{2}^{\text {out }}}}{n_{\mathrm{CO}}^{\text {in }}}\right] \cdot 100 & {[\%]} \\
H_{2} / \mathrm{CO}=\left[\frac{n_{H_{3}^{\text {out }}}}{n_{\mathrm{Cn} \text { out }}}\right]
\end{array}
$$

Direct methane decomposition (DMD) was also carried out in the same experimental device. The following gas composition was equal to $\mathrm{CH}_{4} / \mathrm{Ar}=2 / 8$. The total flow was 100 $\mathrm{cm}^{3} / \mathrm{min}$ which corresponds to a gas hourly space velocity (GHSV) of $20,000 \mathrm{~h}^{-1}$. Similarly, to equation (6), $\mathrm{CH}_{4}$ conversion was calculated as follows:

$$
X_{D M D, C H_{4}}=\left[\frac{n_{\mathrm{CH}_{4}^{\text {in }}}-n_{\mathrm{CH}_{4}^{\text {out }}}}{n_{\mathrm{CH}_{4}^{\text {in }}}}\right] \cdot 100 \quad[\%]
$$

\section{Results and discussion}

\subsection{Catalysts characterization}

Elemental analysis was carried out by means of X-ray fluorescence (XRF). The contents of $\mathrm{Ni}$ and $\mathrm{Y}$, together with the assumed $\mathrm{M}^{2+} / \mathrm{M}^{3+}$ ratio are listed in Table 1 . The studied catalysts showed ca. $20 \mathrm{wt} \%$ of Ni loading, and yttrium contents which are close to the nominal values, i.e. 0.2 and $0.4 \mathrm{wt} \%$. The calculated ratios of $\mathrm{M}^{2+} / \mathrm{M}^{3+}$, i.e. $(\mathrm{Ni}, \mathrm{Mg}) /(\mathrm{Al}, \mathrm{Y})$, were also close to the values which were assumed during the synthesis step. This shows that the studied materials were successfully synthesized, and contents of metals may be easily controlled during the material preparation. 
Table 1 Summary of the structural properties of the calcined catalysts. The values in brackets are nominal values.

\begin{tabular}{|l|r|r|r|r|r|r|}
\hline \multirow{2}{*}{ Catalyst } & \multicolumn{2}{|l|}{ XRF } & \multicolumn{2}{l|}{ Nitrogen sorption } \\
\cline { 2 - 7 } & $\mathrm{Ni}^{2+}[\mathrm{wt} \%]$ & $\mathrm{Y}^{3+}[\mathrm{wt} \%]$ & $\mathrm{M}^{2+} / \mathrm{M}^{3+}[-]$ & $\mathrm{S}_{\mathrm{BET}}\left[\mathrm{m}^{2} / \mathrm{g}\right]^{1)}$ & $\mathrm{V}_{\mathrm{p}}\left[\mathrm{cm}^{3} / \mathrm{g}\right]^{2)}$ & $\mathrm{d}_{\mathrm{p}}[\mathrm{nm}]^{3)}$ \\
\hline $\mathrm{HTNi}$ & 20 & - & $3.6(3.0)$ & 120 & 0.6 & 19 \\
\hline HTNi-Y0.2 & 19 & $0.2(0.2)$ & $3.2(3.0)$ & 127 & 0.5 & 16 \\
\hline HTNi-Y0.4 & 21 & $0.4(0.4)$ & $3.5(3.0)$ & & \\
\end{tabular}

Specific surface area for calcined samples was obtained through BET analysis, and varied from 120 to $127 \mathrm{~m}^{2} / \mathrm{g}$, suggesting no significant influence of yttrium addition on this parameter (Table 1). Total pore volume also remained stable after modification with yttrium. However, pore diameters slightly decreased as compared to HTNi catalyst. Fig. 1 shows IV type isotherms for the calcined materials, which are characteristic for mesoporous structure. [40] The obtained hysteresis loop indicates the slit shaped pores with nonuniform size and shape. The adsorbed amounts decreased with the increasing loading of yttrium, which may possibly be related with observed decrease in pore size (Fig. 2).
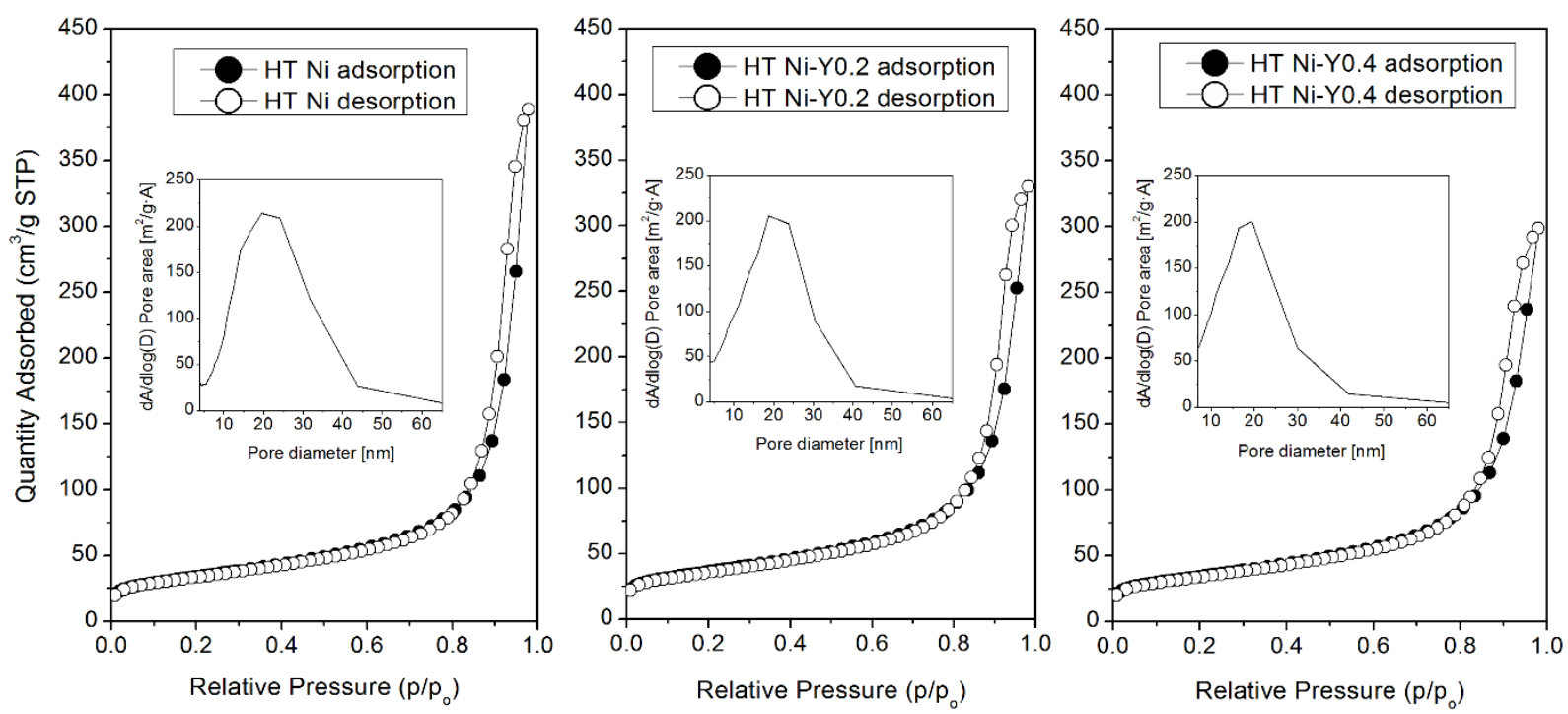

Fig. $1 \mathrm{~N}_{2}$ adsorption/desorption isotherms and pore distribution for HTNi, HTNi-Y0.2 and HTNi-Y0.4 catalysts. 
Fig. 2A presents XRD patterns of the prepared catalysts. For the calcined samples reflections of Ni-Mg-Al mixed oxides (ICOD 00-045-0946) $\left(2 \theta\right.$ ca. $\left.36.7^{\circ}, 43^{\circ}, 62.5^{\circ}\right)$ are observed, which are characteristic for layered double-hydroxides after thermal treatment at $550{ }^{\circ} \mathrm{C}[11,41,42]$. The reduction at $900{ }^{\circ} \mathrm{C}$ resulted in the formation of segregate phase of metallic nickel (ICOD 01-087-0712) as evidenced by reflections at $2 \theta \mathrm{ca} .44 .5^{\circ}, 52^{\circ}, 76.5^{\circ}$ corresponding to crystal planes of (111), (200), (220), respectively (Fig. 2B) [3,31,41]. No separate phase for yttrium was registered in XRD patterns, probably due to small amounts of this metal [3]. Moreover, according to $\mathrm{Li}$ et al.[43] and Taherian et al.[32] promotion with $\mathrm{Y}\left(\mathrm{NO}_{3}\right)_{3} \cdot 6 \mathrm{H}_{2} \mathrm{O}$ resulted in $\mathrm{Y}_{2} \mathrm{O}_{3}$ phase formation which is not further unreducible in our tested conditions. The $\mathrm{Ni}^{\circ}$ crystallite sizes calculated from the width of the reflection at $2 \theta$ of ca. $53^{\circ}$, are shown in Table 2. The yttrium addition resulted in a decrease of nickel crystallites from ca. $8 \mathrm{~nm}$ for the unpromoted HTNi to ca. 5-6 nm for HTNi-Y (Table 2).
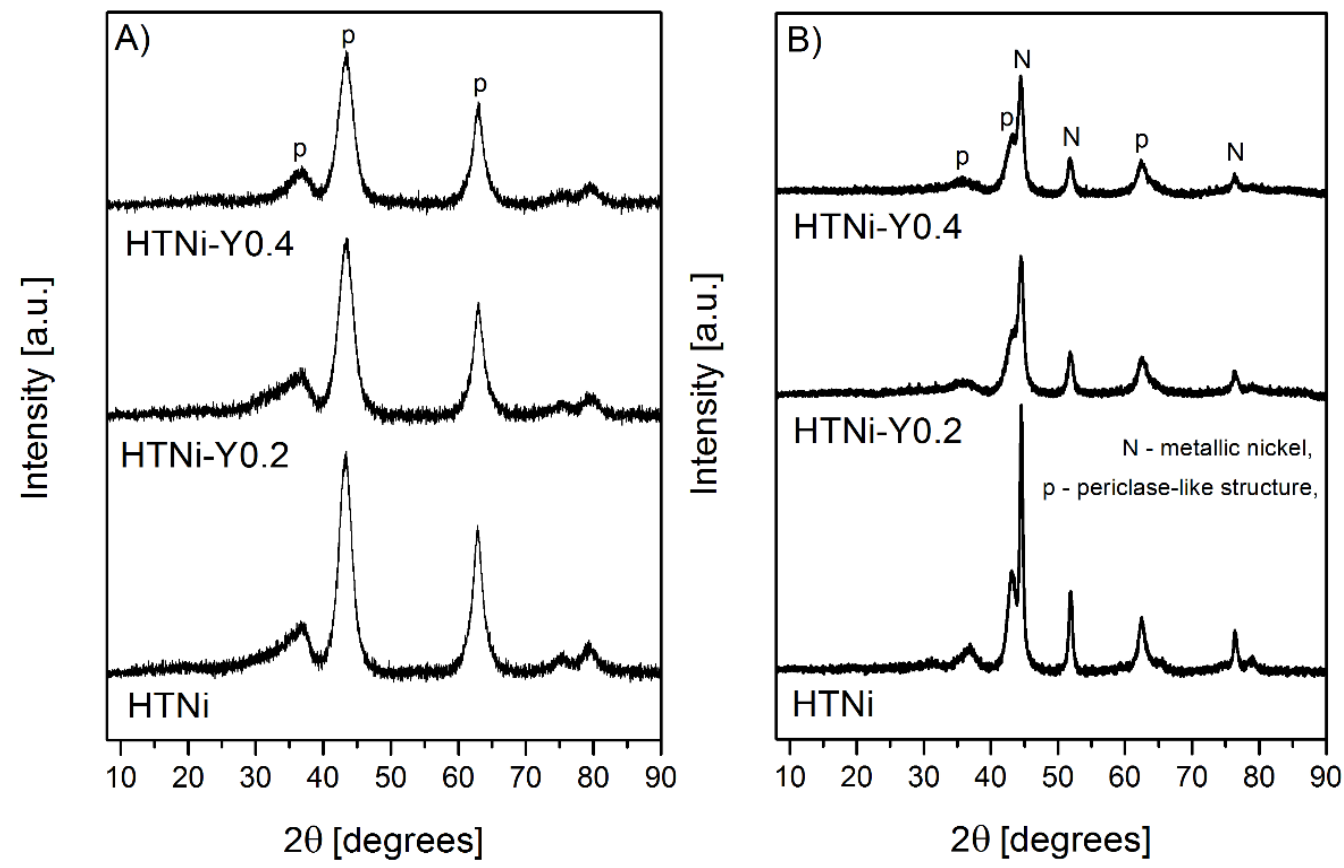

Fig. 2 XRD patterns of a) catalysts after calcination at $550{ }^{\circ} \mathrm{C}$ for $5 \mathrm{~h}$, b) catalysts reduced in $5 \% \mathrm{H}_{2} / \mathrm{Ar}$ mixture at $900{ }^{\circ} \mathrm{C}$ for $1 \mathrm{~h}\left(\mathrm{GHSV}=20,000 \mathrm{~h}^{-1}\right)$. 
Table 2 Nickel crystallite size and metal dispersion for the reduced catalyst, and reducibility and basic properties of the studied catalysts.

\begin{tabular}{|c|c|c|c|c|c|c|c|c|}
\hline \multirow[t]{3}{*}{ Catalyst } & \multirow{3}{*}{$\begin{array}{c}\text { XRD } \\
\mathrm{Ni}^{\mathrm{o}} \\
\text { crystallite } \\
\text { size }^{1)} \\
{[\mathrm{nm}]}\end{array}$} & \multicolumn{2}{|c|}{$\mathrm{H}_{2}$ chemisorption } & \multirow{3}{*}{$\begin{array}{c}\mathrm{TPR}_{-\mathrm{H}_{2}} \\
\mathrm{H}_{2} \\
\text { consumption } \\
{\left[\mathrm{mmol} \mathrm{H}_{2} / \mathrm{g}\right]}\end{array}$} & \multicolumn{4}{|c|}{$\mathrm{TPD}-\mathrm{CO}_{2}$} \\
\hline & & & Dispersion & & \multicolumn{4}{|c|}{ Number of basic sites $[\mu \mathrm{mol} / \mathrm{g}]$} \\
\hline & & $\begin{array}{c}\text { size }^{2)} \\
{[\mathrm{nm}]}\end{array}$ & {$[\%]$} & & Weak & Medium & Strong & $\begin{array}{c}\text { Total } \\
\text { basicity }\end{array}$ \\
\hline HTNi & 8 & 11 & 8.9 & 0.209 & 16 & 44 & 46 & 107 \\
\hline HTNi-Y0.2 & 6 & 10 & 9.5 & 0.143 & 12 & 32 & 19 & 63 \\
\hline HTNi-Y0.4 & 5 & 9 & 10.7 & 0.151 & 16 & 20 & 23 & 59 \\
\hline
\end{tabular}

\footnotetext{
1) Based on the Scherrer equation, from the width at half-maximum of the XRD reflections at $2 \Theta$ ca. $53^{\circ}$.

2) From $\mathrm{H}_{2}$ chemisorption assuming spherical crystallites of uniform size, calculated from equation (5).
}

The reducibility of the catalysts was studied by $\mathrm{TPR}-\mathrm{H}_{2}$. Hydrogen consumption for the reduced samples, presented in Table 2, decreased after yttrium addition. The highest consumption of $0.209 \mathrm{mmol} \mathrm{H}_{2} / \mathrm{g}$ was observed for non-modified HTNi catalyst. After yttrium promotion the hydrogen uptake decreased to $0.143 \mathrm{mmol} \mathrm{H}_{2} / \mathrm{g}_{\mathrm{cat}}$ and $0.151 \mathrm{mmol} \mathrm{H}_{2} / \mathrm{g}$ for HTNi-Y0.2 and HTNi-Y0.4 catalysts, respectively. The decrease of reducibility has been reported before for the materials modified with higher yttrium contents of 0.6 and $1.5 \mathrm{wt} \%$ [3]. Fig. 3 presents TPR-H $\mathrm{H}_{2}$ profiles for studied LDHs. Two wide peaks with maxima at 386 and $829^{\circ} \mathrm{C}$ are registered for HTNi catalyst. They may be ascribed to $\mathrm{NiO}$ weakly-bonded to the surface of the material and nickel oxides present in the $\mathrm{Ni}-\mathrm{Mg}-\mathrm{Al}$ mixed oxides originating from layered double hydroxides, respectively [44-47]. According to $\mathrm{Hu}$ et al. [48] only a part of nickel can be reduced, i.e. $\mathrm{Ni}-\mathrm{O}-\mathrm{Ni}$ species, and it is not possible to reduce $\mathrm{Ni}-\mathrm{O}-\mathrm{Mg}$. After the yttrium addition a rightward shift of the maximum temperature peak $\left(\mathrm{T}_{\max }\right)$ was reported, which indicates stronger interaction of $\mathrm{Ni}$ species with the support as compared to HTNi catalyst. For HTNi-Y0.4 catalyst, the shift was less evident, as revealed in $\mathrm{T}_{\max }\left(866{ }^{\circ} \mathrm{C}\right)$. 
Similar observations were reported by Huang et al. [21] for $\mathrm{NiO}-\mathrm{Al}_{2} \mathrm{O}_{3}$ materials modified with $\mathrm{Y}_{2} \mathrm{O}_{3}$, and $\mathrm{Y} / \mathrm{HTNi}$ catalysts with higher loading of yttrium [3].

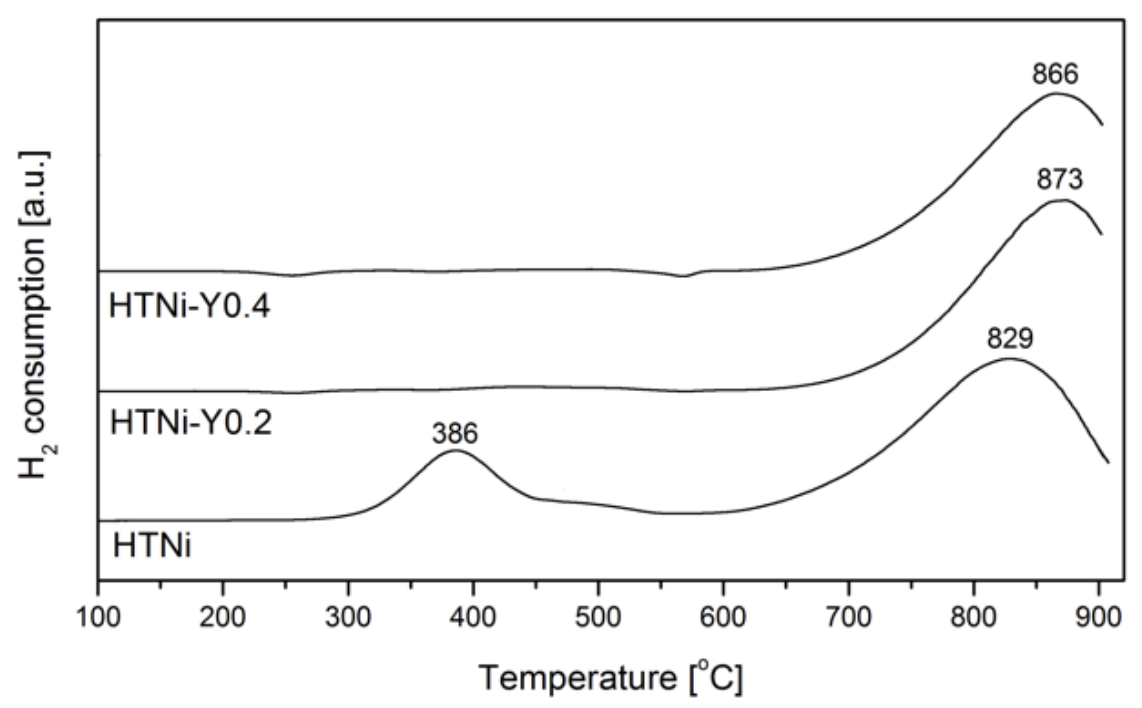

Fig. 3 TPR-H2 profiles recorded over HTNi, HTNi-Y0.2 and HTNi-Y0.4.

Table 2 presents Ni dispersion calculated from $\mathrm{H}_{2}$ chemisorption. There is a small increase of metallic nickel after the modification with yttrium, i.e. from for HTNi to 9.5 and $10.7 \%$ for HTNi-Y0.2 and HTNi-Y0.4, respectively. The enhanced dispersion has been observed before in other Y modified catalysts, and it had beneficial effect on catalytic performance in DRM. Better dispersed nickel particles make them more accessible for the reaction with methane in dry reforming of methane process. The improved dispersion is linked with smaller crystal size, as confirmed by calculation assuming spherical crystallites of uniform size (Table 2). The obtained values agree well with the XRD estimates, i.e. in both characterization techniques a decrease of Ni crystallites was observed after Y promotion. A number of studies have shown that $\mathrm{H}_{2}$ or $\mathrm{CO}$ chemisorption results are in line with values obtained from XRD [49-52]. This result affects the catalytic behavior of the studied materials, as will be described in the catalytic tests section. 


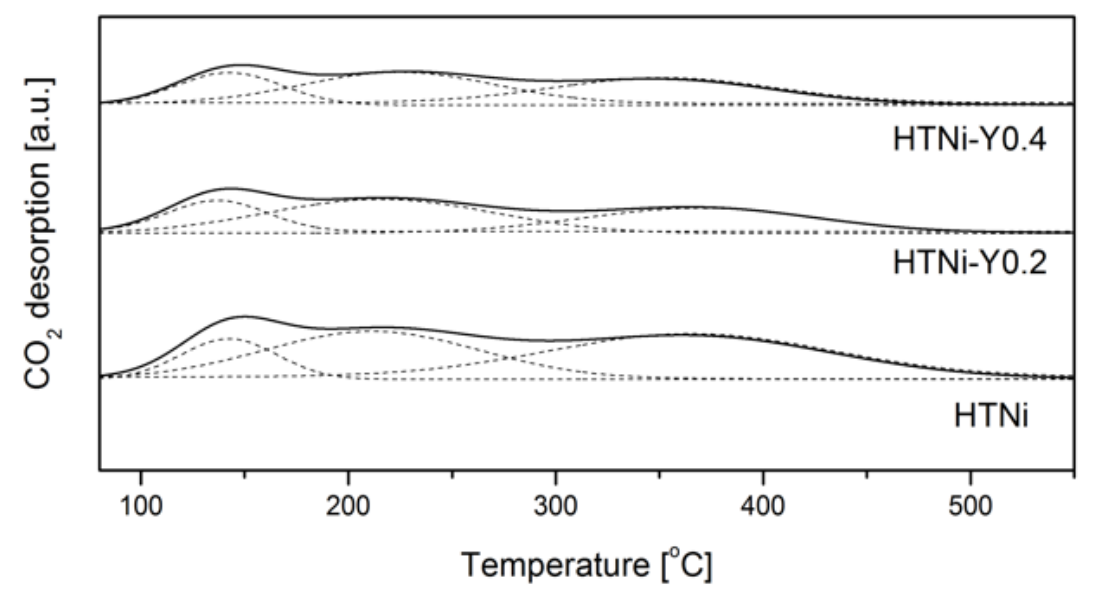

Fig. 4 TPD-CO 2 patterns recorded over the catalysts reduced at $900^{\circ} \mathrm{C}$.

Basic properties were investigated by TPD- $\mathrm{CO}_{2}$. The results of the basicity measurements are shown in Fig. 4. Weak, medium and strong basic sites could be distinguished, respectively, with maximum peaks at the temperature range of (i) $100-150{ }^{\circ} \mathrm{C}$ (Brønsted basic sides with surface $\mathrm{OH}^{-}$), (ii) ca. $190{ }^{\circ} \mathrm{C}$ (medium-strength Lewis acid-base pairings) and (iii) ca. $280{ }^{\circ} \mathrm{C}$ (strong Lewis basic sites arising from low-coordination surface $\mathrm{O}^{2-}$ ) $[3,33,45,46,53]$. Table 2 presents the calculated number of basic sites, with the highest value for HTNi catalyst. A similar value of total basicity was reported by Dębek et al. [17] and assumed as an optimal for DRM. For Y-doped catalysts this parameter decreased, being the lowest for HTNi-Y0.2. A decrease of total basicity caused by $\mathrm{Zr}$, Ce or Y promotion has been reported elsewhere $[3,42,54,55]$. Although, the basicity was lower it did not negatively affect DRM performance of the promoted catalysts. Indeed, the modification with $\mathrm{Zr}$, Ce or Y resulted in better stability and/or activity.

\subsection{Catalytic tests of dry reforming of methane}

A first series of experiments was performed while keeping the catalysts at certain temperatures, starting from 850 to $600{ }^{\circ} \mathrm{C}$. Figs. $5 \mathrm{~A}-\mathrm{C}$ present the $\mathrm{CH}_{4}$ and $\mathrm{CO}_{2}$ conversion and the $\mathrm{H}_{2} / \mathrm{CO}$ ratio for $\mathrm{HTNi}-\mathrm{Y}$ catalysts. One can find that yttrium promoted the activity of Ni- 
containing layered double hydroxides. The unmodified HTNi showed the lowest values, both for $\mathrm{CH}_{4}$ and $\mathrm{CO}_{2}$ conversion (Figs. 5A, 5B), as well as $\mathrm{H}_{2} / \mathrm{CO}$ molar ratio (Fig. 5C). The addition of $\mathrm{Y}$ significantly improved the catalytic performance. In the temperature range of $600-700{ }^{\circ} \mathrm{C}$ the samples promoted with 0.2 and 0.4 wt. $\%$ of $\mathrm{Y}$ presented conversion of $\mathrm{CO}_{2}$ higher than the one reported for the unmodified catalyst. However, an opposite effect was registered at temperatures higher than $700{ }^{\circ} \mathrm{C}$, in which the $\mathrm{Y}$ promotion led to higher $\mathrm{CH}_{4}$ conversion. Considering the $\mathrm{H}_{2} / \mathrm{CO}$ ratio, it was always below unity at all temperatures. The values were much higher for the Y-promoted catalysts at least in the $600-800{ }^{\circ} \mathrm{C}$ temperature range, reaching 0.98 at temperature above $750{ }^{\circ} \mathrm{C}$.

Table 3. Side reactions occurring during dry reforming of methane.

\begin{tabular}{|l|l|c|}
\hline \multicolumn{1}{|c|}{ Reaction } & \multicolumn{1}{|c|}{ Equation } & $\Delta \mathrm{H}^{\theta}[\mathrm{kJ} / \mathrm{mol}]$ \\
\hline Reverse water gas shift & $\mathrm{CO}_{2}+\mathrm{H}_{2}=\mathrm{H}_{2} \mathrm{O}+\mathrm{CO}$ & 41 \\
\hline Hydrogenation of $\mathrm{CO}_{2}$ & $\mathrm{CO}_{2}+2 \mathrm{H}_{2}=\mathrm{C}_{(\mathrm{s})}+2 \mathrm{H}_{2} \mathrm{O}$ & -90 \\
\hline Boudouard Reaction & $2 \mathrm{CO}=\mathrm{C}_{(\mathrm{s})}+\mathrm{CO}_{2}$ & -172 \\
\hline Direct methane decomposition & $\mathrm{CH}_{4}=\mathrm{C}_{(\mathrm{s})}+2 \mathrm{H}_{2}$ & 75 \\
\hline Steam on $\mathrm{C}$ & $\mathrm{C}_{(\mathrm{s})}+\mathrm{H}_{2} \mathrm{O}=\mathrm{CO}+\mathrm{H}_{2}$ & 131 \\
\hline
\end{tabular}

The positive effect of the $\mathrm{Y}$ promotion was observed before for Ni and Y-modified $\mathrm{Al}_{2} \mathrm{O}_{3}$ [28], Y-doped Ni/SBA-15 [29,43], (Ni-Y)/KIT-6 [31], NiO- $\mathrm{Y}_{2} \mathrm{O}_{3}-\mathrm{Al}_{2} \mathrm{O}_{3}$ [21], Y-doped $\mathrm{Ce}_{0.75} \mathrm{Zr}_{0.25} \mathrm{O}_{2}$ [30], and more recently, for Ni-layered double hydroxides based catalysts with higher loadings of yttrium [3]. The enhanced conversion observed for Y promoted catalysts can be directly linked with a smaller particle size of $\mathrm{Ni}^{\circ}$ observed both by XRD and $\mathrm{H}_{2}$ chemisorption. It is in good agreement with the appropriate values registered in this work (cp. Table 2). $\mathrm{CO}_{2}$ conversion, which was reported to be slightly higher than that of $\mathrm{CH}_{4}$, and the values of $\mathrm{H}_{2} / \mathrm{CO}$ ratio lower than 1 at certain temperatures may be ascribed to the side reaction occurrence, i.e. reverse water gas-shift (RWGS) (Table 3) [21]. Moreover, when more $\mathrm{CH}_{4}$ was 
converted compared to $\mathrm{CO}_{2}$, the other side reactions such as direct methane decomposition and Boudouard reaction could take place [45].
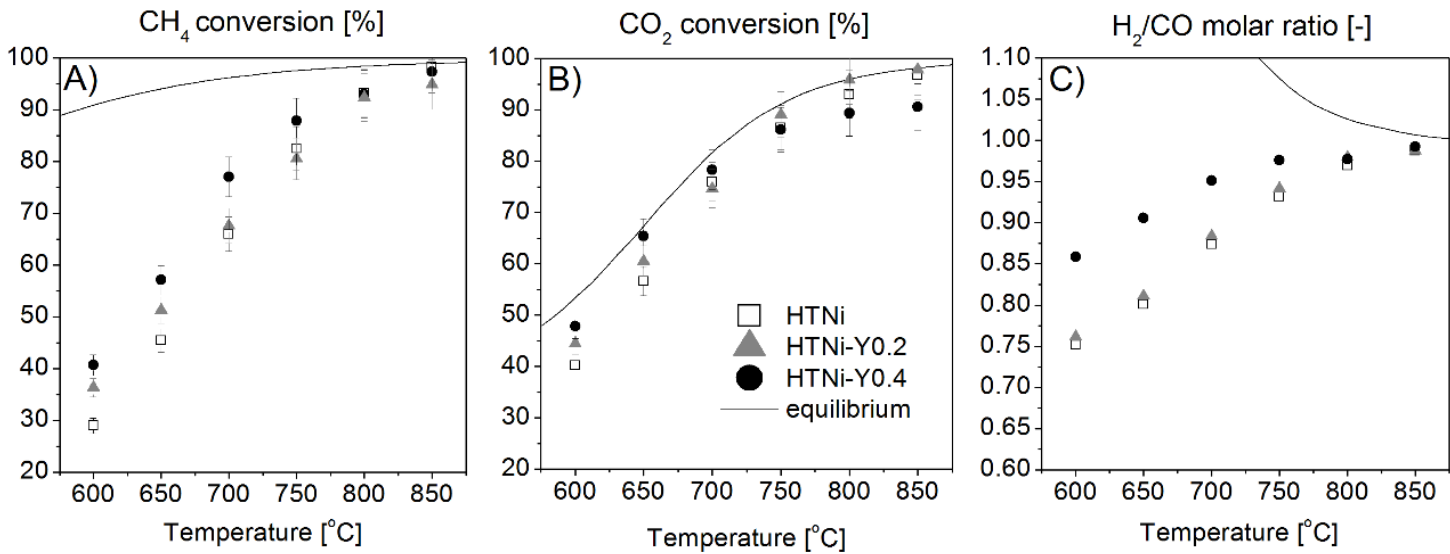

Fig. 5 Catalytic DRM tests as a function of temperature, steady-state measurements after 30 min at each temperature (GHSV=20,000 h$~ h^{-1}, \mathrm{CH}_{4} / \mathrm{CO}_{2} / \mathrm{Ar}=1 / 1 / 8$, total flow rate $\left.100 \mathrm{~cm}^{3} / \mathrm{min}^{-1}\right)$.
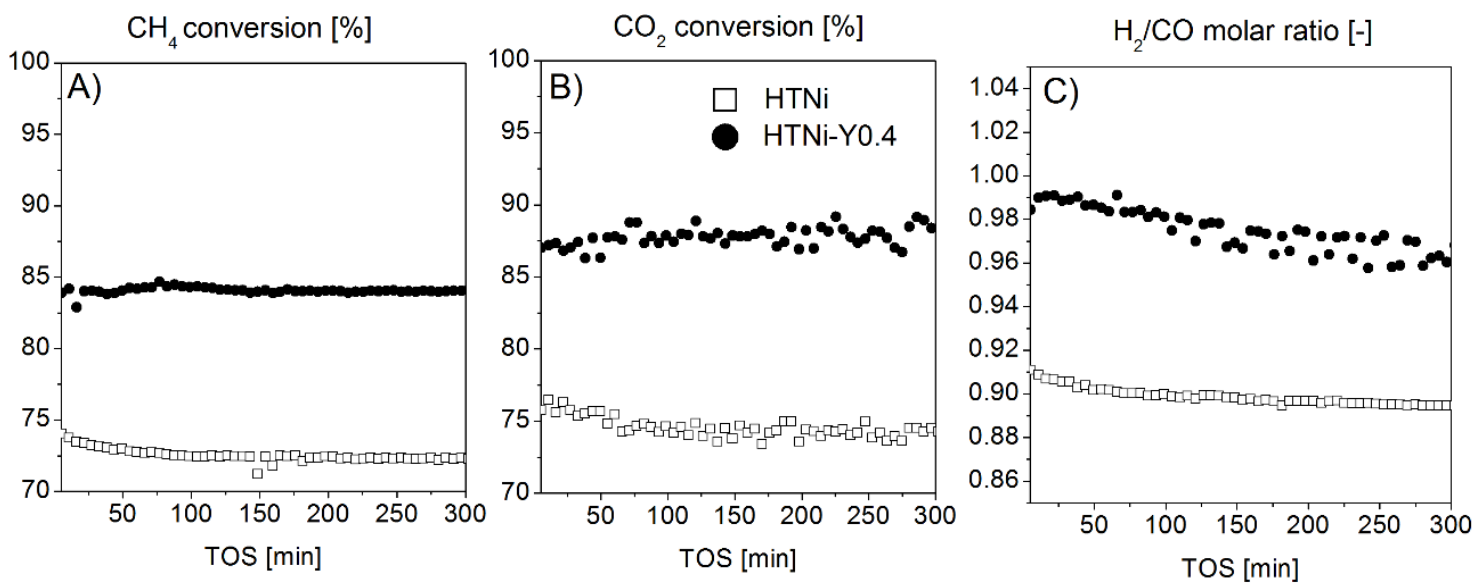

Fig. 6 Catalytic DRM tests at $700{ }^{\circ} \mathrm{C}\left(\mathrm{GHSV}=20,000 \mathrm{~h}^{-1}, \mathrm{CH}_{4} / \mathrm{CO}_{2} / \mathrm{Ar}=1 / 1 / 8\right.$, total flow rate $\left.100 \mathrm{~cm}^{3} / \mathrm{min}\right)$.

A second series of experiments was performed at $700{ }^{\circ} \mathrm{C}$ for 5 hours. Only HTNi-Y0.4 and HTNi were tested (after the reduction at $900{ }^{\circ} \mathrm{C}$ ). The results are presented in Fig. 6. The catalytic activity of Y promoted catalyst was higher than that of HTNi. In the isothermal test, 
the difference in conversion is even more marked for both $\mathrm{CH}_{4}$ and $\mathrm{CO}_{2}$, with $\mathrm{CH}_{4}$ conversion of $84 \%$ for $\mathrm{Y}$ doped catalyst versus only $72 \%$ for the non-modified material, and $\mathrm{CO}_{2}$ conversion of $87 \%$ for $Y$ the doped catalyst versus only $75 \%$ for the non-doped material. In the isothermal conditions, the $\mathrm{CO}_{2}$ conversion is still higher than $\mathrm{CH}_{4}$ conversion, which may suggest the occurrence of RWGS (Table 3). The $\mathrm{H}_{2} / \mathrm{CO}$ molar ratio, which is higher for $\mathrm{Y}$ promoted materials, is always lower than unity. The results agree with those obtained as a function of temperature (Figs. 5A, 5B, 5C). In the isothermal conditions, we clearly see that $\mathrm{CH}_{4}$ conversion is stable after $5 \mathrm{~h}$ for $\mathrm{HTNi}-\mathrm{Y} 0.4$ catalyst, while a slight deactivation is observed for the non-promoted material.

Based on the literature $[2,10]$, the DRM mechanism is driven by 2 main reactions (i) decomposition of methane on nickel active site and (ii) dissociative adsorption of $\mathrm{CO}_{2}$ on the metal surface and metal-surface interface. Promotion with yttrium resulted in the small Ni crystallite size, known to hinder direct decomposition of methane (DMD). Dissociative adsorption of $\mathrm{CO}_{2}$ highly depends on basic properties of the catalysts. High number of strong basic sites leads to strong $\mathrm{CO}_{2}$ adsorption which cannot further react with $\mathrm{CH}_{4}$ molecule, and, and this, as a consequence, leads to the DMD [45]. Appropriate basicity provides good catalytic performance in dry reforming of methane, together with the suppression of carbon forming reactions. Moreover, a number of studies showed a positive effect of $\mathrm{Y}_{2} \mathrm{O}_{3}$ promotion on the rate of carbon removal due to oxygen vacancies, which induced oxygen radicals from $\mathrm{CO}_{2}$ to react with coke $[32,38,43,56,57]$. Thus, a possible removal of carbon could have taken place (to some extend) according to the reverse Boudouard reaction (Table 3) [43].

In order to better understand the catalysts behavior in terms of side reactions and avoid any deactivation, the direct methane decomposition (DMD) was carried out over HTNi and HTNiY0.4 catalysts. The results are presented in Fig. 7, where DMD is more dominant for HTNi. During the $\mathrm{CH}_{4}$ decomposition experiment, stable methane conversion was registered for HTNi 
catalyst, whereas HTNi-Y0.4 showed decreasing values after first $30 \mathrm{~min}$, pointing to an evolution of surface properties resulting in the suppression of this reaction. Small Ni crystallite size calculated for the Y-promoted sample could have contributed to this phenomenon, similar as reported in the study of Dębek et al. [41]. It illustrates that the Y promotion inhibited the direct methane decomposition, and thus the $\mathrm{C}$ formation.

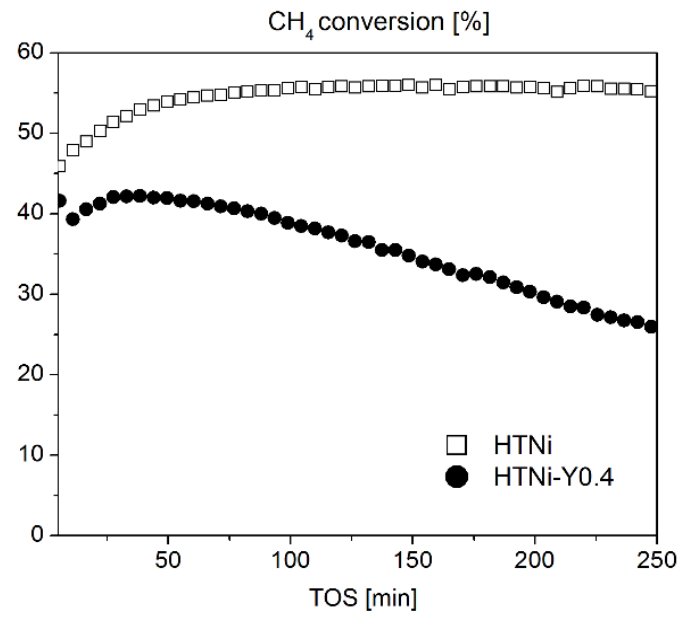

Fig. 7 Catalytic tests of direct methane decomposition as a function of temperature (GHSV=20,000 $\mathbf{h}^{-1}$, $\mathrm{CH}_{4} / \mathrm{Ar}=2 / 8$, total flow rate $\left.100 \mathrm{~cm}^{3} / \mathrm{min}\right)$.

The carbon suppression has been already reported for Y-promoted materials in other studies $[31,43]$.

\subsection{Catalysts characterization after isothermal DRM tests}

As reported in Table 4, the specific surface of the unpromoted spent catalyst remained constant (125 compared to $120 \mathrm{~m}^{2} / \mathrm{g}$ ), whereas the $\mathrm{S}_{\mathrm{BET}}$ decreased significantly for the $\mathrm{Y}$ promoted spent catalyst ( 95 vs. $120 \mathrm{~m}^{2} / \mathrm{g}$ ). This decrease may be explained by the carbon deposition occurring upon the DRM. No changes in pore volumes and diameters of pores were registered. 
Table 4. Textural and structural properties of the spent catalysts.

\begin{tabular}{|c|c|c|c|c|c|}
\hline \multirow[t]{2}{*}{ Catalyst } & \multicolumn{3}{|c|}{ Nitrogen sorption } & XRD & \multirow{2}{*}{$\begin{array}{r}\text { Raman } \\
\mathrm{I}_{\mathrm{D}} / \mathrm{I}_{\mathrm{G}}\end{array}$} \\
\hline & $\begin{array}{l}\mathrm{S}_{\mathrm{BET}}^{1)} \\
{\left[\mathrm{m}^{2} / \mathrm{g}\right]}\end{array}$ & $\begin{array}{c}\mathrm{V}_{\mathrm{p}}^{2)} \\
{\left[\mathrm{cm}^{3} / \mathrm{g}\right]}\end{array}$ & $\begin{array}{c}\mathrm{d}_{\mathrm{p}}^{3)} \\
{[\mathrm{nm}]}\end{array}$ & $\begin{array}{r}\mathrm{Ni}^{\circ} \text { crystallite size }{ }^{4)} \\
{[\mathrm{nm}]}\end{array}$ & \\
\hline HTNi & 125 & 0.3 & 10 & 7 & 1.83 \\
\hline HTNi-Y0.4 & 108 & 0.3 & 10 & 6 & 1.65 \\
\hline \multicolumn{6}{|c|}{ specific surface areas calculated from the BET equation } \\
\hline \multicolumn{6}{|c|}{ 2) mesopore volumes derived from the BJH desorption isotherm } \\
\hline \multicolumn{6}{|c|}{ istribution obtained from the BJH desorption isotherm } \\
\hline 4) based on $t$ & on, $\mathrm{fi}$ & width at & 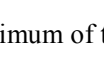 & reflection & \\
\hline
\end{tabular}

XRD diffractograms have been recorded over the spent catalysts in order to verify the $\mathrm{Ni}^{\circ}$ crystallite size, the possible changes in the support after the catalytic process, and the carbon formation. The results are presented in Fig. 8, where reflections typical for metallic nickel (ICOD 01-087-0712) and periclase-like mixed oxides can be found (ICOD 00-045-0946) $[31,45,46,58]$, similarly as for the reduced samples (cp. Fig. 3). Crystallite size of $\mathrm{Ni}^{\circ}$ did not change significantly after the tests. For both catalysts the values are close to the ones recorded for the reduced samples, i.e. 8 and $5 \mathrm{~nm}$ versus 7 and $6 \mathrm{~nm}$ for HT and HTNi-Y0.4, respectively. This suggests the lack of sintering of the nickel particles upon DRM and then confirm the stability of Y doped catalyst during DRM in stability runs. Additionally, reflections of graphite

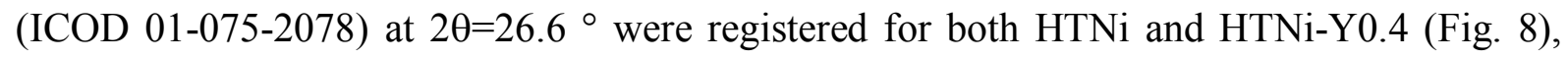
which shows that the studied materials have suffered a deactivation during time on stream experiments. For the HTNi catalyst additional reflections of $\mathrm{Mg}_{6} \mathrm{Al}_{2}(\mathrm{OH})_{16} \mathrm{CO}_{3} \cdot 4 \mathrm{H}_{2} \mathrm{O}(\mathrm{ICOD}$ 00-014-0191) have been registered at $2 \theta=11.5^{\circ}$ and $22.9^{\circ}$. This phase is typical for LDHs after synthesis and before calcination at around $500{ }^{\circ} \mathrm{C}[6,41,53]$. The presence of the hydroxides (H) has been reported before for Ni-based LDHs after DRM tests, and indicates a partial 
regeneration of the support in the presence of water. The latter could have been produced during side reactions, such as RWGS or hydrogenation during DRM as reported elsewhere [33,41].

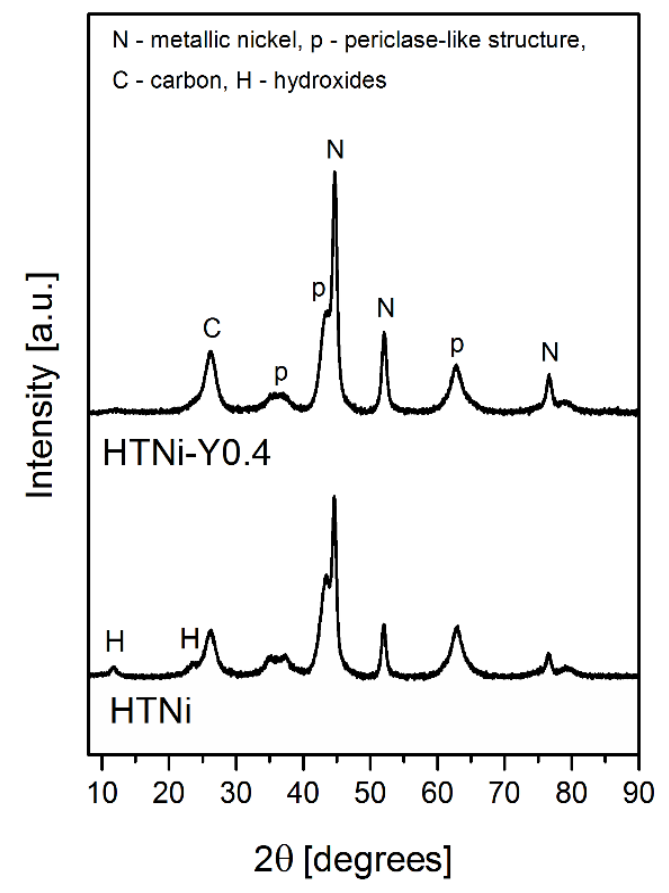

Fig. 8 XRD diffractograms of the spent catalysts $\left(\mathrm{CH}_{4} / \mathrm{CO}_{2} / \mathrm{Ar}=1 / 1 / 8,700{ }^{\circ} \mathrm{C}\right.$ for $\left.5 \mathrm{~h}\right)$.

TGA-MS data are presented in Fig. 9, where mass loss of 27\% and 32\% was registered for HTNi and HTNi-Y0.4, respectively. Also, a small weight increase may be observed at $300{ }^{\circ} \mathrm{C}$ for both spent catalysts. According to Tsyganok et al. [59], this increase arises from $\mathrm{Ni}^{\circ}$ oxidation to $\mathrm{NiO}$. Moreover, the registered MS data revealed that the weight decrease was linked to $\mathrm{CO}_{2}$ formation, which occurs due to the oxidation of carbonaceous species, formed upon dry reforming of methane $[3,59,60]$. The peaks of $\mathrm{CO}_{2}$ were found at ca. $600{ }^{\circ} \mathrm{C}$, which mainly suggests the formation of carbon filaments [11]. Their presence was considerably higher for HTNi-Y0.4 as compared to Y-free catalyst. The formation of carbon filaments cannot be, however, linked directly with the $\mathrm{CH}_{4}$ decomposition because of the limitation of this reaction for HTNi-Y0.4 (cp. Fig. 7). 

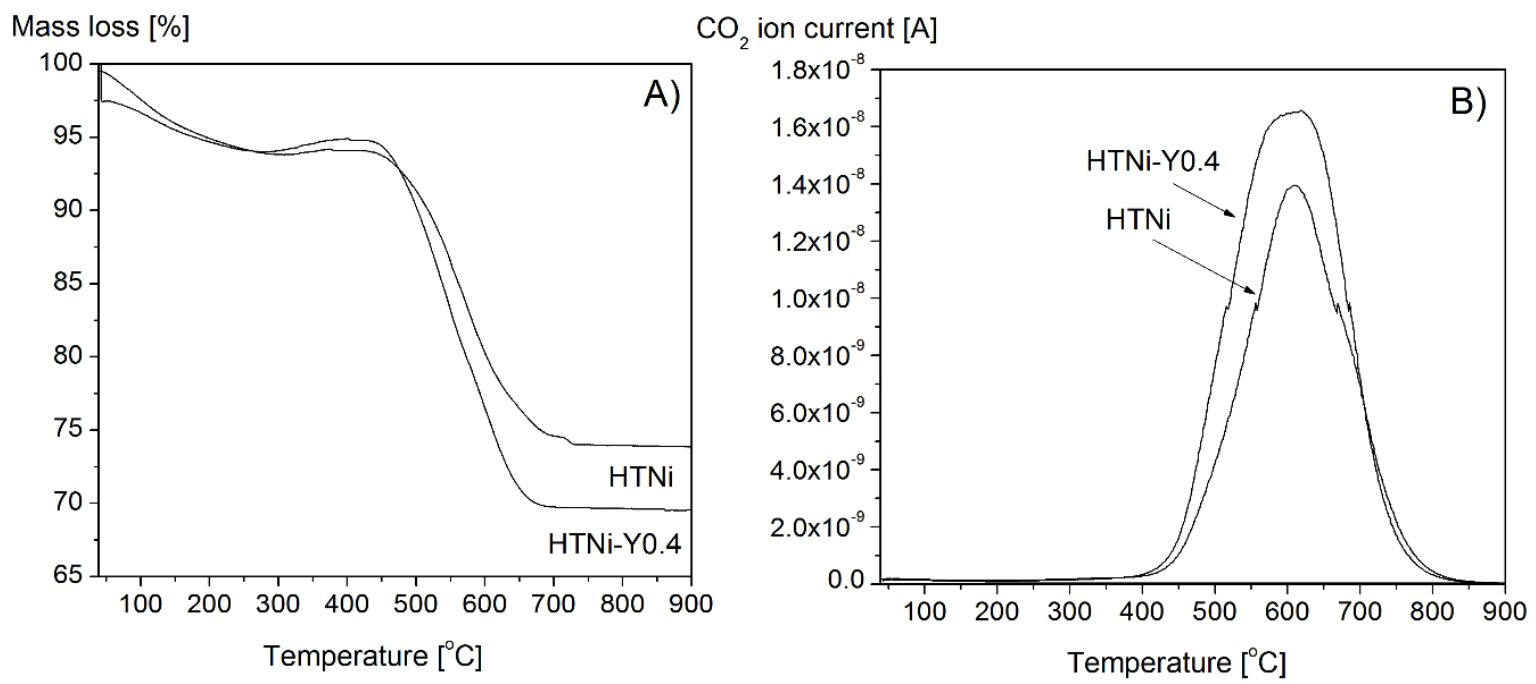

Fig. 9 TGA-MS over the spent catalyst $\left(\mathrm{CH}_{4} / \mathrm{CO}_{2} / \mathrm{Ar}=1 / 1 / 8,700{ }^{\circ} \mathrm{C}\right.$ for $\left.5 \mathrm{~h}\right)$.

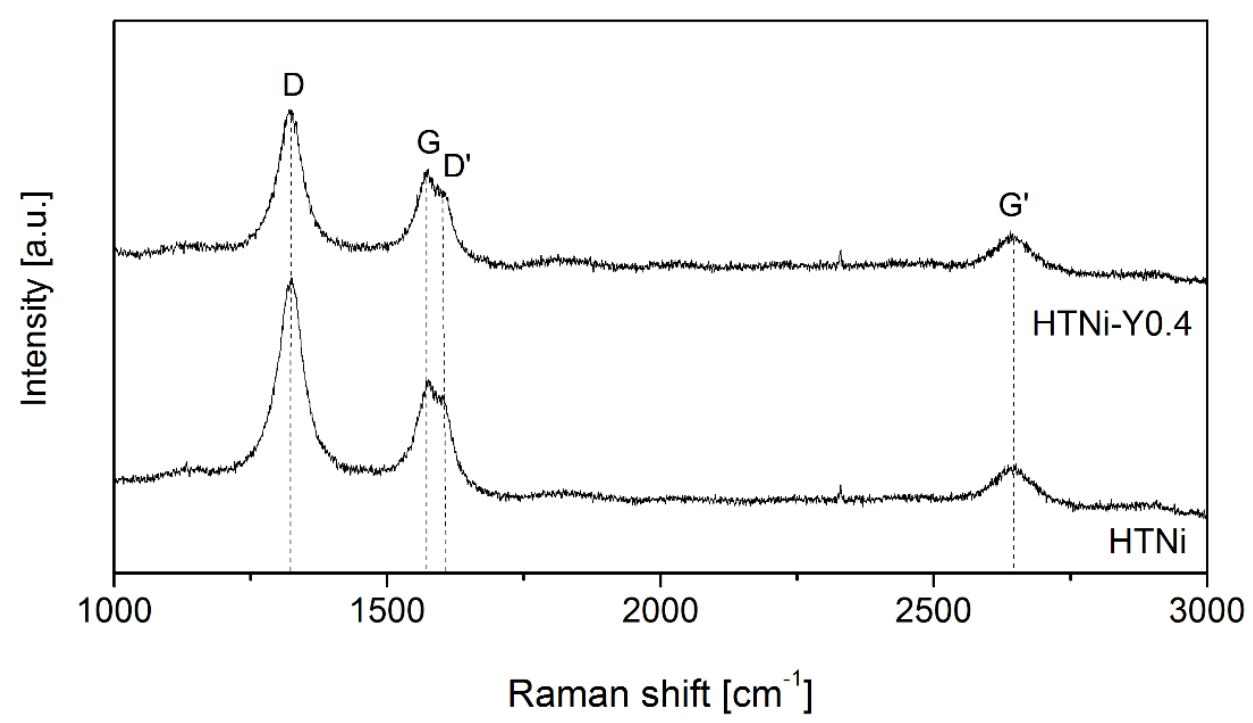

Fig. 10 Raman spectra over the spent catalysts $\left(\mathrm{CH}_{4} / \mathrm{CO}_{2} / \mathrm{Ar}=1 / 1 / 8,700{ }^{\circ} \mathrm{C}\right.$ for $\left.5 \mathrm{~h}\right)$.

Raman spectroscopy was used to examine the properties of carbonaceous species on the spent HTNi and HTNi-Y0.4 catalysts. For both materials, four bands were registered at the following Raman shift: $1324 \mathrm{~cm}^{-1}$ (D band), $1573 \mathrm{~cm}^{-1}$ (G band), $1600 \mathrm{~cm}^{-1}$ (D' band) and 2647 $\mathrm{cm}^{-1}$ (G' band) (Fig. 10). The $\mathrm{D}$ and $\mathrm{D}^{\prime}$ bands arise from a disorder present in graphite structure and they have been ascribed to the non-zone centered phonons associated to the disorderinduced vibration of $\mathrm{C}-\mathrm{C}$ bond. The $\mathrm{G}$ and $\mathrm{G}^{\prime}$ bands refer to the stretching vibration in the 
aromatic layers of graphite and they are only present in perfect crystalline graphite [61]. Table 4 presents the calculated ratios of $\mathrm{I}_{\mathrm{D}} / \mathrm{I}_{\mathrm{G}}$, which describe the graphitization degree of carbon and the disorder in its structure. The $\mathrm{Y}$-modified material showed lower $\mathrm{I}_{\mathrm{D}} / \mathrm{I}_{\mathrm{G}}$ ratio, i.e. 1.65 versus 1.83 for HTNi. One can conclude that the $\mathrm{C}$ deposited on $\mathrm{Y}$ promoted materials is more graphitic and thus more difficult to remove upon DRM [62]. This shows that low loadings of yttrium influenced the DRM mechanism in favoring side reactions, such as for example $\mathrm{CO}_{2}$ hydrogenation. Indeed, it was observed in Figs. $6 \mathrm{~B}$ and $6 \mathrm{C}$, a slight increase in $\mathrm{CO}_{2}$ conversion only for HTNi-Y0.4 catalyst with a simultaneous decrease of the $\mathrm{H}_{2} / \mathrm{CO}$ ratio, showing a possible consumption of $\mathrm{H}_{2}$ during the DRM only for the promoted catalysts.

\section{Conclusions}

Dry reforming of methane was studied over Ni-based layered double hydroxides precursors modified with low loadings of yttrium, i.e. 0.2 and $0.4 \mathrm{wt} \%$. The catalysts were prepared by the co-precipitation method in the presence of $\mathrm{NaOH}$ and $\mathrm{Na}_{2} \mathrm{CO}_{3}$. In the isothermal test at $700{ }^{\circ} \mathrm{C}$, the promoted $\mathrm{HTNi}-\mathrm{Y} 0.4$ catalyst was found to be the most active with a $\mathrm{CH}_{4}$ conversion of ca. 84\%. A slight increase in $\mathrm{CO}_{2}$ conversion (increasing from $86.8 \%$ to $88.4 \%$ in $5 \mathrm{~h}$ time on stream test) has been also registered, together with a decrease in $\mathrm{H}_{2} / \mathrm{CO}$ ratio. This shows a possible consumption of $\mathrm{H}_{2}$ during the overall DRM for promoted catalyst, whereas a stable $\mathrm{H}_{2} / \mathrm{CO}$ ratio was found for $\mathrm{HTNi}$ catalyst. Thus, this carbon formation could be due to $\mathrm{CO}_{2}$ hydrogenation $\left(\mathrm{CO}_{2}+2 \mathrm{H}_{2}=\mathrm{C}_{(\mathrm{s})}+2 \mathrm{H}_{2} \mathrm{O}\right)$ leading to a decrease in $\mathrm{H}_{2}$ in the gas phase and a decrease of $\mathrm{H}_{2} / \mathrm{CO}$ ratio during DRM.

Graphitic type of carbon was recorded in the spent catalysts, which led to a decrease of the specific surface, and a greater mass loss during TGA-MS test. In the latter, $\mathrm{CO}_{2}$ formation was recorded at $600{ }^{\circ} \mathrm{C}$, which suggests filamentous carbon formation. More graphitic carbon was confirmed by Raman for HTNi-Y0.4 sample than for HTNi material. However, a partial 
regeneration of support has been observed and revealed as a presence of $\mathrm{Mg}_{6} \mathrm{Al}_{2}(\mathrm{OH})_{16} \mathrm{CO}_{3} \cdot 4 \mathrm{H}_{2} \mathrm{O}$ reflections in XRD patterns only in the unpromoted catalyst (HTNi). This shows that Y promotion leads to a better structural resistance to the side reactions which produce $\mathrm{H}_{2} \mathrm{O}$, e.g. reverse-water gas shift or other reaction, such as $\mathrm{CO}_{2}$ hydrogenation.

\section{Acknowledgments}

K. Świrk acknowledges the French Embassy in Poland for her grant "BGF Doctorat en cotutelle" between Sorbonne University and AGH University of Science and Technology. InnoEnergy $\mathrm{PhD}$ school and AGH (grant 15.11.210.440) are acknowledged for the financial support. This work was carried out within the framework of Erasmus + traineeship of K. Świrk at NTNU (the KinCat Catalysis Group). T. Grzybek and M. Motak thank AGH grant 11.11.210.373. 


\section{References}

[1] M.F. Mark, W.F. Maier, F. Mark, Reaction kinetics of the $\mathrm{CO} 2$ reforming of methane, Chem. Eng. Technol. 20 (1997) 361-370. doi:10.1002/ceat.270200602.

[2] H. Seo, Recent scientific progress on developing supported Ni catalysts for dry (CO2) reforming of methane, Catalysts. 8 (2018) 110-128. doi:10.3390/catal8030110.

[3] K. Świrk, M.E. Gálvez, M. Motak, T. Grzybek, M. Rønning, P. Da Costa, Yttrium promoted Ni-based double-layered hydroxides for dry methane reforming, J. CO2 Util. 27 (2018) 247-258. doi:10.1016/j.jcou.2018.08.004.

[4] G.K. Reddy, S. Loridant, A. Takahashi, P. Delichère, B.M. Reddy, Reforming of methane with carbon dioxide over $\mathrm{Pt} / \mathrm{ZrO} 2 / \mathrm{SiO} 2$ catalysts - Effect of zirconia to silica ratio, Appl. Catal. A Gen. 389 (2010) 92-100. doi:10.1016/j.apcata.2010.09.007.

[5] J. Zhang, H. Wang, A.K. Dalai, Development of stable bimetallic catalysts for carbon dioxide reforming of methane, J. Catal. 249 (2007) 300-310. doi:10.1016/j.jcat.2007.05.004.

[6] A.I. Tsyganok, M. Inaba, T. Tsunoda, S. Hamakawa, K. Suzuki, T. Hayakawa, Dry reforming of methane over supported noble metals: A novel approach to preparing catalysts, Catal. Commun. 4 (2003) 493-498. doi:10.1016/S1566-7367(03)00130-4.

[7] M.S. Fan, A.Z. Abdullah, S. Bhatia, Utilization of greenhouse gases through dry reforming: Screening of nickel-based bimetallic catalysts and kinetic studies, ChemSusChem. 4 (2011) 1643-1653. doi:10.1002/cssc.201100113.

[8] O. Muraza, A. Galadima, A review on coke management during dry reforming of methane, Int. J. Energy Res. 39 (2015) 1196-1216. doi:10.1002/er.

[9] D. Chen, R. Lødeng, A. Anundskås, O. Olsvik, A. Holmen, Deactivation during carbon dioxide reforming of methane over Ni catalyst: Microkinetic analysis, Chem. Eng. Sci. 56 (2001) 1371-1379. doi:10.1016/S0009-2509(00)00360-2.

[10] N.A.K. Aramouni, J.G. Touma, B.A. Tarboush, J. Zeaiter, M.N. Ahmad, Catalyst design for dry reforming of methane: Analysis review, Renew. Sustain. Energy Rev. 82 (2018) 2570-2585. doi:10.1016/j.rser.2017.09.076.

[11] C.E. Daza, S. Moreno, R. Molina, Co-precipitated Ni-Mg-Al catalysts containing Ce for CO2 reforming of methane, Int. J. Hydrogen Energy. 36 (2011) 3886-3894. doi:10.1016/j.ijhydene.2010.12.082.

[12] E. Alper, O. Yuksel Orhan, CO2 utilization: Developments in conversion processes, Petroleum. 3 (2017) 109-126. doi:10.1016/j.petlm.2016.11.003.

[13] R. Dębek, M. Motak, T. Grzybek, M. Galvez, P. Da Costa, A short review on the catalytic activity of hydrotalcite-derived materials for dry reforming of methane, Catalysts. 7 (2017) 32-57. doi:10.3390/catal7010032.

[14] F. Cavani, F. Trifirò, A. Vaccari, Hydrotalcite-type anionic clays: Preparation, properties and applications., Catal. Today. 11 (1991) 173-301. doi:10.1016/09205861(91)80068-K.

[15] A. Bhattacharyya, V.W. Chang, D.J. Schumacher, CO2 reforming of methane to syngas I: Evaluation of hydrotalcite clay-derived catalysts, Appl. Clay Sci. 13 (1998) 317-328. doi:10.1016/S0169-1317(98)00030-1.

[16] M.M. Nair, S. Kaliaguine, F. Kleitz, Nanocast LaNiO3 perovskites as precursors for the preparation of coke-resistant dry reforming catalysts, ACS Catal. 4 (2014) 38373846.

[17] K. Takehira, Recent development of layered double hydroxide-derived catalysts Rehydration, reconstitution , and supporting , aiming at commercial application -, Appl. Clay Sci. 136 (2017) 112-141. doi:10.1016/j.clay.2016.11.012.

[18] Q. Zhang, T. Zhang, Y. Shi, B. Zhao, M. Wang, Q. Liu, J. Wang, K. Long, Y. Duan, P. 
Ning, A sintering and carbon-resistant Ni-SBA-15 catalyst prepared by solid-state grinding method for dry reforming of methane, J. CO2 Util. 17 (2017) 10-19. doi:10.1016/j.jcou.2016.11.002.

[19] M.N. Kaydouh, N. El Hassan, A. Davidson, S. Casale, H. El Zakhem, P. Massiani, Highly active and stable Ni/SBA-15 catalysts prepared by a "two solvents" method for dry reforming of methane, Microporous Mesoporous Mater. 220 (2016) 99-109. doi:10.1016/j.micromeso.2015.08.034.

[20] J.W. Han, C. Kim, J.S. Park, H. Lee, Highly coke-resistant Ni nanoparticle catalysts with minimal sintering in dry reforming of methane, ChemSusChem. 7 (2014) 451456. doi:10.1002/cssc.201301134.

[21] X. Huang, G. Xue, C. Wang, N. Zhao, N. Sun, W. Wei, Y. Sun, Highly stable mesoporous $\mathrm{NiO}-\mathrm{Y} 2 \mathrm{O} 3-\mathrm{Al} 2 \mathrm{O} 3$ catalysts for $\mathrm{CO} 2$ reforming of methane: effect of $\mathrm{Ni}$ embedding and Y2O3 promotion, Catal. Sci. Technol. 6 (2016) 449-459. doi:10.1039/C5CY01171J.

[22] A. Becerra, M. Dimitrijewits, C. Arciprete, A.C. Luna, Stable Ni / Al 2 O 3 catalysts for methane dry reforming Effects of pretreatment, Granul. Matter. 3 (2001) 79-81.

[23] L. Jin, B. Ma, S. Zhao, X. He, Y. Li, H. Hu, Ni/MgO-Al2O3 catalyst derived from modified [Ni, Mg,Al]-LDH with $\mathrm{NaOH}$ for $\mathrm{CO} 2$ reforming of methane, 3 (2017) 0-9. doi:10.1016/j.ijhydene.2017.12.087.

[24] X. Feng, J. Feng, W. Li, Insight into $\mathrm{MgO}$ promoter with low concentration for the carbon - deposition resistance of $\mathrm{Ni}$ - based catalysts in the $\mathrm{CO} 2$ reforming of $\mathrm{CH} 4$, 39 (2018) 88-98. doi:10.1016/S1872-2067(17)62928-0.

[25] N.D. Charisiou, L. Tzounis, V. Sebastian, S.J. Hinder, M.A. Baker, K.

Polychronopoulou, M.A. Goula, Investigating the correlation between deactivation and the carbon deposited on the surface of Ni/Al2O3and Ni/La2O3-A12O3catalysts during the biogas reforming reaction, Appl. Surf. Sci. (2018).

doi:10.1016/j.apsusc.2018.05.177.

[26] N.D. Charisiou, G. Siakavelas, L. Tzounis, V. Sebastian, A. Monzon, M.A. Baker, S.J. Hinder, K. Polychronopoulou, An in depth investigation of deactivation through carbon formation during the biogas dry reforming reaction for Ni supported on modified with CeO 2 and La 2 O 3 zirconia catalysts, Int. J. Hydrogen Energy. 43 (2018) 1895518976. doi:10.1016/j.ijhydene.2018.08.074.

[27] N.D. Charisiou, A.B.V.G.P.M.A. Goula, Synthesis Gas Production via the Biogas Reforming Reaction Over Ni / MgO - Al 2 O 3 and Ni / CaO - Al 2 O 3 Catalysts, Waste and Biomass Valorization. 7 (2016) 725-736. doi:10.1007/s12649-016-9627-9.

[28] B. Li, W. Su, X. Wang, X. Wang, Alumina supported Ni and Co catalysts modified by Y2O3 via different impregnation strategies: Comparative analysis on structural properties and catalytic performance in methane reforming with $\mathrm{CO} 2$, Int. J. Hydrogen Energy. 41 (2016) 14732-14746. doi:10.1016/j.ijhydene.2016.06.219.

[29] B. Li, S. Zhang, Methane reforming with CO2 using nickel catalysts supported on yttria-doped SBA-15 mesoporous materials via sol-gel process, Int. J. Hydrogen Energy. 38 (2013) 14250-14260. doi:10.1016/j.ijhydene.2013.08.105.

[30] Q. Wu, J. Chen, J. Zhang, Effect of yttrium and praseodymium on properties of $\mathrm{Ce} 0.75 \mathrm{Zr} 0.25 \mathrm{O} 2$ solid solution for $\mathrm{CH} 4-\mathrm{CO} 2$ reforming, Fuel Process. Technol. 89 (2008) 993-999. doi:10.1016/j.fuproc.2008.03.006.

[31] K. Świrk, M.E. Gálvez, M. Motak, T. Grzybek, M. Rønning, P. Da Costa, Syngas production from dry methane reforming over yttrium-promoted nickel-KIT-6 catalysts, Int. J. Hydrogen Energy. (2018). doi:10.1016/j.ijhydene.2018.02.164.

[32] Z. Taherian, M. Yousefpour, M. Tajally, B. Khoshandam, A comparative study of $\mathrm{ZrO} 2, \mathrm{Y} 2 \mathrm{O} 3$ and $\mathrm{Sm} 2 \mathrm{O} 3$ promoted Ni/SBA-15 catalysts for evaluation of 
CO2/methane reforming performance, Int. J. Hydrogen Energy. 42 (2017) 1640816420. doi:10.1016/j.ijhydene.2017.05.095.

[33] K. Świrk, M.E. Gálvez, M. Motak, T. Grzybek, M. Rønning, P. Da Costa, Dry reforming of methane over $\mathrm{Zr}$ - and $\mathrm{Y}$-modified $\mathrm{Ni} / \mathrm{Mg} / \mathrm{Al}$ double-layered hydroxides, Catal. Commun. 117 (2018) 26-32. doi:doi.org/10.1016/j.catcom.2018.08.024.

[34] L. Luo, S. Li, Y. Zhu, The effects of yttrium on the hydrogenation performance and surface properties of a ruthenium-supported catalyst, J. Serbian Chem. Soc. 70 (2005) 1419-1425. doi:10.2298/JSC0512419L.

[35] J.M. Francis, W.H. Whitlow, The effect of yttrium on the high temperatureoxidation resistance of some Fe-Cr base alloys in carbon dioxide, Corros. Sci. 5 (1965) 701-710. doi:10.1016/S0010-938X(65)80026-9.

[36] L. Ilieva, P. Petrova, G. Pantaleo, R. Zanella, J.W. Sobczak, W. Lisowski, Z. Kaszkur, G. Munteanu, I. Yordanova, L.F. Liotta, A.M. Venezia, T. Tabakova, Alumina supported $\mathrm{Au} / \mathrm{Y}$-doped ceria catalysts for pure hydrogen production via PROX, Int. J. Hydrogen Energy. (2018). doi:10.1016/j.ijhydene.2018.03.005.

[37] L. Ilieva, A. Venezia, P. Petrova, G. Pantaleo, L. Liotta, R. Zanella, Z. Kaszkur, T. Tabakova, Effect of Y Modified Ceria Support in Mono and Bimetallic Pd-Au Catalysts for Complete Benzene Oxidation, Catalysts. 8 (2018) 283. doi:10.3390/catal8070283.

[38] J.D.A. Bellido, E.M. Assaf, Effect of the Y2O3-ZrO2 support composition on nickel catalyst evaluated in dry reforming of methane, Appl. Catal. A Gen. 352 (2009) 179187. doi:10.1016/j.apcata.2008.10.002.

[39] D.G. Mustard, C.H. Bartholomew, Determination of Metal Crystallite Supported Size and Morphology Supported Nickel Catalysts, J. Catal. 67 (1981) 186-206. doi:10.1016/0021-9517(81)90271-2.

[40] D. Wierzbicki, R. Baran, R. Dębek, M. Motak, T. Grzybek, M.E. Gálvez, P. Da Costa, The influence of nickel content on the performance of hydrotalcite-derived catalysts in CO2 methanation reaction, Int. J. Hydrogen Energy. 42 (2017) 23548-23555. doi:10.1016/j.ijhydene.2017.02.148.

[41] R. Dębek, M. Motak, D. Duraczyska, F. Launay, M.E. Galvez, T. Grzybek, P. Da Costa, Methane dry reforming over hydrotalcite-derived $\mathrm{Ni}-\mathrm{Mg}-\mathrm{Al}$ mixed oxides: the influence of Ni content on catalytic activity, selectivity and stability, Catal. Sci. Technol. 6 (2016) 6705-6715. doi:10.1039/C6CY00906A.

[42] R. Dębek, M. Motak, M.E. Galvez, T. Grzybek, P. Da Costa, Promotion effect of zirconia on $\mathrm{Mg}(\mathrm{Ni}, \mathrm{Al}) \mathrm{O}$ mixed oxides derived from hydrotalcites in $\mathrm{CO} 2$ methane reforming, Appl. Catal. B Environ. (2018) 36-46. doi:10.1016/j.apcatb.2017.06.024.

[43] J.F. Li, C. Xia, C.T. Au, B.S. Liu, Y2O3-promoted NiO/SBA-15 catalysts highly active for CO2/CH4 reforming, Int. J. Hydrogen Energy. 39 (2014) 10927-10940. doi:10.1016/j.ijhydene.2014.05.021.

[44] R. Dębek, M. Motak, M.E. Galvez, T. Grzybek, P. Da Costa, Influence of Ce/Zr molar ratio on catalytic performance of hydrotalcite-derived catalysts at low temperature $\mathrm{CO} 2$ methane reforming, Int. J. Hydrogen Energy. 42 (2017) 1-12. doi:10.1016/j.ijhydene.2016.12.121.

[45] R. Dębek, M. Radlik, M. Motak, M.E. Galvez, W. Turek, P. Da Costa, T. Grzybek, Nicontaining Ce-promoted hydrotalcite derived materials as catalysts for methane reforming with carbon dioxide at low temperature - On the effect of basicity, Catal. Today. 257 (2015) 59-65. doi:10.1016/j.cattod.2015.03.017.

[46] H. Liu, D. Wierzbicki, R. Debek, M. Motak, T. Grzybek, P. Da Costa, M.E. Gálvez, La-promoted Ni-hydrotalcite-derived catalysts for dry reforming of methane at low temperatures, Fuel. 182 (2016) 8-16. doi:10.1016/j.fuel.2016.05.073. 
[47] M. Broda, A.M. Kierzkowska, D. Baudouin, Q. Imtiaz, C. Copéret, C.R. Müller, Sorbent-enhanced methane reforming over a Ni-Ca-based, bifunctional catalyst sorbent, ACS Catal. 2 (2012) 1635-1646. doi:10.1021/cs300247g.

[48] Y.H. Hu, Solid-solution catalysts for $\mathrm{CO} 2$ reforming of methane, Catal. Today. 148 (2009) 206-211. doi:10.1016/j.cattod.2009.07.076.

[49] Y.J.O. Asencios, C.B. Rodella, E.M. Assaf, Oxidative reforming of model biogas over NiO-Y2O3-ZrO2 catalysts, Appl. Catal. B Environ. 132-133 (2013) 1-12. doi:10.1016/j.apcatb.2012.10.032.

[50] A.M. Venezia, L.F. Liotta, G. Pantaleo, V. La Parola, G. Deganello, A. Beck, Z. Koppány, K. Frey, D. Horváth, L. Guczi, Activity of SiO2 supported gold-palladium catalysts in CO oxidation, Appl. Catal. A Gen. 251 (2003) 359-368. doi:10.1016/S0926-860X(03)00343-0.

[51] A.L. Bonivardi, M.A. Baltanás, Preparation of Pd SiO2cfor methanol synthesis III. Exposed metal fraction and hydrogen solubility, J. Catal. 138 (1992) 500-517. doi:10.1016/0021-9517(92)90302-X.

[52] J.H. Sepúlveda, N.S. Fígoli, The influence of calcination temperature on Pd dispersion and hydrogen solubility in Pd/SiO2, Appl. Surf. Sci. 68 (1993) 257-264. doi:10.1016/0169-4332(93)90130-4.

[53] D. Wierzbicki, R. Debek, M. Motak, T. Grzybek, M.E. Gálvez, P. Da Costa, Novel NiLa-hydrotalcite derived catalysts for CO2 methanation, Catal. Commun. 83 (2016) 5-8. doi:10.1016/j.catcom.2016.04.021.

[54] R. Dębek, M.E. Galvez, F. Launay, M. Motak, T. Grzybek, P. Da Costa, Low temperature dry methane reforming over $\mathrm{Ce}, \mathrm{Zr}$ and $\mathrm{CeZr}$ promoted $\mathrm{Ni}-\mathrm{Mg}-\mathrm{Al}$ hydrotalcite-derived catalysts, Int. J. Hydrogen Energy. 41 (2016) 11616-11623. doi:10.1016/j.ijhydene.2016.02.074.

[55] R. Dębek, M. Motak, M.E. Galvez, P. Da Costa, T. Grzybek, Catalytic activity of hydrotalcite-derived catalysts in the dry reforming of methane: on the effect of Ce promotion and feed gas composition, React. Kinet. Mech. Catal. 121 (2017) 185-208. doi:10.1007/s11144-017-1167-1.

[56] A. Daneshmand-Jahromi, Sanaz; Reza, Rahimpour Mohammad; Meshksar, Maryam; Hafiz, Hydrogen Production from Cyclic Chemical Looping Steam Methane Reforming over Yttrium Promoted Ni/SBA-16 Oxygen Carrier, Catalysts. 7 (2017) 286. doi:10.3390/catal7100286.

[57] A.A. Lytkina, N. V. Orekhova, M.M. Ermilova, A.B. Yaroslavtsev, The influence of the support composition and structure (MXZr1-XO2-d) of bimetallic catalysts on the activity in methanol steam reforming, Int. J. Hydrogen Energy. 43 (2018) 198-207. doi:10.1016/j.ijhydene.2017.10.182.

[58] H. Shang, K. Pan, L. Zhang, B. Zhang, X. Xiang, Enhanced activity of supported Ni catalysts promoted by $\mathrm{Pt}$ for rapid reduction of aromatic nitro compounds, Nanomaterials. 6 (2016) 103-117. doi:10.3390/nano6060103.

[59] A.I. Tsyganok, T. Tsunoda, S. Hamakawa, K. Suzuki, K. Takehira, T. Hayakawa, Dry reforming of methane over catalysts derived from nickel-containing $\mathrm{Mg}$-Al layered double hydroxides, J. Catal. 213 (2003) 191-203. doi:10.1016/S0021-9517(02)000477.

[60] J. Niu, S.E. Liland, J. Yang, K.R. Rout, J. Ran, D. Chen, Effect of oxide additives on the hydrotalcite derived Ni catalysts for $\mathrm{CO} 2$ reforming of methane, Chem. Eng. J. (2018) 0-1. doi:10.1016/j.cej.2018.08.149.

[61] I. Luisetto, S. Tuti, C. Battocchio, S. Lo Mastro, A. Sodo, Ni/CeO2-A12O3 catalysts for the dry reforming of methane: The effect of CeAlO3content and nickel crystallite size on catalytic activity and coke resistance, Appl. Catal. A Gen. 500 (2015) 12-22. 
doi:10.1016/j.apcata.2015.05.004.

[62] E. Le Saché, J.L. Santos, T.J. Smith, M.A. Centeno, H. Arellano-Garcia, J.A. Odriozola, T.R. Reina, Multicomponent Ni-CeO2 nanocatalysts for syngas production from $\mathrm{CO} 2 / \mathrm{CH} 4$ mixtures, J. CO2 Util. 25 (2018) 68-78.

doi:10.1016/j.jcou.2018.03.012. 